\title{
Simulating land use of prehistoric wetland settlements: did excessive resource use necessitate a highly dynamic settlement system?
}

\author{
Tilman Baum \\ Integrated Prehistory and \\ Archaeological Science, \\ University of Basel, \\ Spalenring 144, CH-4055 Basel \\ Email: tilman.baum@unibas.ch
}

\begin{abstract}
In the European circumalpine region, remains of wetland settlements that were constructed on lake shores and in peat-bogs have been investigated for more than 150 years. Interdisciplinary research provides detailed evidence on many facets of prehistoric subsistence. This project aims at some fundamental questions related to the land-use and the settlement system, that are today either controversially debated or unclear. To this aim, an agent-based simulation model of an idealized, hypothetical settlement located in the alpine forelands in the $4^{\text {th }}$ Millennium BC is set up: WELASSIMO (Wetland Settlement Simulator). The main problems to tackle are: I) to assess the sustainability of the land-use system, II) to investigate the systemic effects of neolithic subsistence on the environment and III) to identify potential limiting factors for the system. The observer is enabled to investigate the close connection and the relevance of the subsystems for the whole system.
\end{abstract}

\section{INTRODUCTION}

$\mathrm{F}$ ROM the archaeological investigation of findings in peat-bog and lake-shore sediments in the North-Western pre-alpine forelands, it is known that people built their wooden houses in these locations from the $4^{\text {th }}$ to the first Millennium BC [1]. In more than 150 years of interdisciplinary research, detailed knowledge has been gained from the excavations and analysis of the oxygen-depleted layers and remains of wooden house piles. However, a striking gap exists between highly resolved knowledge on certain issues, and some very fundamental, yet unsolved questions. Thus, it is known exactly which plant and animal species have been consumed [2], but the husbandry and land use methods are contradictory discussed [3], [4]. Evidence is for a highly dynamic settlement system and a short occupation time of many sites, yet the reasons are as unclear as the feedback mechanisms inside of the system [5]. This project aims at these questions using a systemic approach. My assumption is, that intensive resource use and degrading ecosystem services were the key factors determining the high mobility of

This work is supported by the "Evangelisches Studienwerk Villigst e.V." the wetland settlements. Accordingly, my approach is to test whether the reconstructed land-use system could have been sustainable for a prolonged period.

\section{Regional AND ARChaeOlogical Setting}

WELASSIMO is simulating a hypothetical, idealized settlement, but I used data from several sites that have been excavated to a significant extent as a reference. Fig. 1 shows the three main sites that were used to this aim. All sites are located in South-Western Germany in the vicinity of Lake Constance. The physical landscape is largely influenced by the Würmian glaciation, as documented by numerous lakes of various sizes, kettle-hole peat-bogs, drumlin fields and wide areas of relatively fertile soils on glacial till. The subcontinental climatic conditions are locally favorable with relatively mild winters and mostly warm and humid summers. The site Ho1A (Hornstaad-Hörnle, 3918 - ca. 3905 BC) is located near the outlet of Lake Constance into the River Rhine. It was fully excavated, and a large body of evidence is published on archaeological and ecological questions, e.g. [6], [7], [8]. Up to 45 houses were inhabited contemporaneously, each of which is interpreted by the authors as an individual economic unit. I use their interpretation for the sake of simplicity, despite new studies that demonstrate how the social system is likely to have been more complex than the equation House $=$ household $=$ nuclear family [9]. At the site $\mathrm{Si}$ (Sipplingen-Osthafen), up to 15 anthropogenic debris layers bear witness of frequent settlement activities. Dendrotypological studies on the wooden house posts yield evidence of forest management systems, such as the use of primeval forest, the existence of coppiced forests, or intensive forest thinning [10]. For this project, I refer to the layers Sil and Si2 (3919-3904 BC). The third settlement is De1A (Degersee), which was constructed at the shores of a small lake in the beginning of the $39^{\text {th }}$ century $\mathrm{BC}$ and inhabited for a few years only. It was partially excavated recently, and only preliminary results are published until now, e.g [11]. 


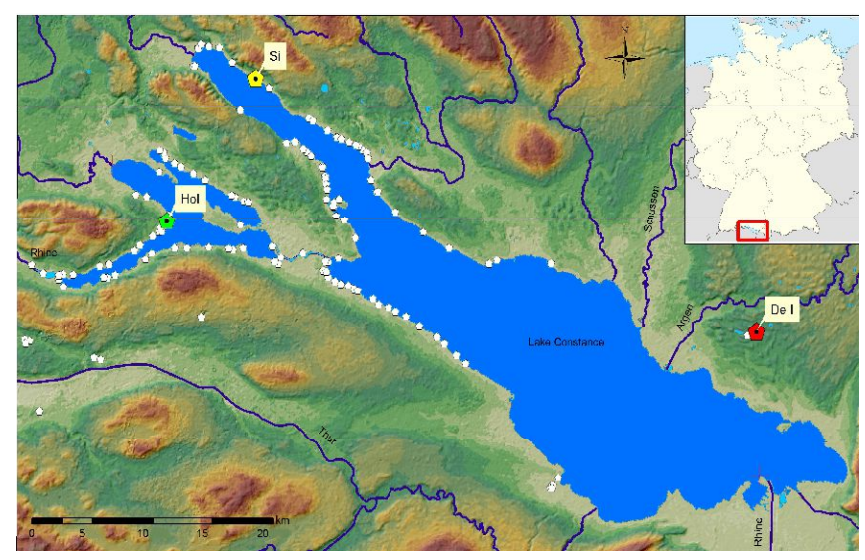

Fig 1. Distribution of pile-dwellings and peat bog sites near Lake Constance in SW-Germany and NE-Switzerland (not complete). Ho I:Hornstaad-Hoernle 1. Si: Sipplingen-Osthafen. De I: Degersee 1. Figure taken from [11]

\section{The ECONOMic System: DATA AND Hypotheses}

The general properties of the system have been described by various authors in relative consistency, e.g. [1], [2], [12] and can thus be described as follows. The inhabitants of the wetland settlements lived on a mixed diet comprising of products from crop and livestock husbandry, hunting, gathering and fishing. They built elevated houses in close proximity to or directly in shallow lake areas or in peat bog. The mean lifespan of the houses was only several years [5], and accordingly, the occupation time of many of the sites was short. The interpretation of published data by the individual authors with respect to the internal functioning of the subsystems, however, is not consistent [3], [4]. This is especially true for the crop husbandry system. The major hypotheses on land-use related subsystems are:

\section{A. Shifting Cultivation (SC)}

The main arguments for this hypothesis on crop husbandry is evidence of frequent large-scale fires and for an anthropogenic increase in shrub-land vegetation at the beginning of the $4^{\text {th }}$ Millennium BC. Several authors interpret these phenomena as a result of a land-use system that is based on ash fertilization of the crop fields, e.g. [3]. Massive nutrient input allows for high yields, while the need for fuel wood and very intense weed growth soon after the fire would require an annually shifting of the fields. Based on experimental reconstruction of this system, I assume annually varying yields with a long-term average of $3000 \mathrm{~kg} / \mathrm{ha}$ for shifting cultivation. Annual variation of the yield due to weather is accounted for in all husbandry systems.

\section{B. Intensive Garden Cultivation (IGC)}

Well-preserved crop stores have been analyzed using the FIBS-approach [13]. The ecological properties of the plants are interpreted as evidence for a crop husbandry regime, that is - in contrast to $A$ - based on permanent fields, which are cultivated for more than just a couple of years [4]. The analysis of isotope relations of the cereal grains make probable the use of animal dung for manuring of the fields, so that a small-scale, permanent and highly intensive cultivation is reconstructed [14]. Here, I assume an average yield of 2400 $\mathrm{kg} / \mathrm{ha}$, also with annual variation due to weather events.

\section{Non-Intensive Cultivation (NIC)}

This scenario is basically the same as $B$, but with the difference that no manure is applied and thus, yields are markedly lower and soil nutrient depletion may occur after some time. I assume an average yield of $1100 \mathrm{~kg} / \mathrm{ha}$.

\section{Livestock husbandry regimes}

The relative importance of livestock, especially cattle, is debated; while cattle bones with signs of butchery are found frequently, the reconstruction of an approximate number of cattle kept per person varies [15]. This is important not only with respect to the nutritional significance of livestock, but also in relation to the possible amount of manure available for IGC. As forest covered nearly all available land, large areas were possibly needed for forest pasture.

\section{E. Forest management strategies}

An ubiquitous and mostly well - preserved element of the wetland sites are the remains of wooden construction piles. The analysis of their tree-ring patterns yields not only an absolute dating for the felling of the trees, but also information on the structural and compositional features of the forest stand they grew in [10]. While coppiced forest or single tree selection dominated in some phases, in others only a few old trees seemed to be available. Likely for the ease of processing, quite young trees with a diameter of $5-20 \mathrm{~cm}$ were preferred in the beginning of the $4^{\text {th }}$ Millennium. As these are not necessarily available in adequate numbers in a primeval forest, a suitable stand certainly constituted a valuable resource.

\section{THE MODEL}

WELASSIMO is an agent-based simulation model of the system "pre-alpine wetland settlement" and its major subsystems, as shown in fig. 2. Agents are units of interest contributing to the system, programmed in specific software environment (here: NETLOGO). Agents in WELASSIMO are: "households", comprising of an averaged 6 inhabitants; individual heads of livestock; secondary forest patches (age $<50$ years); primary forest patches (age $>50$ years); cereal field patches. For the formulation of the agent's internal specifications and the necessary calculations, I reverted mainly on the published palaeoecological and archaeological data on wetland sites in the North-Western pre-alpine forelands of the $4^{\text {th }}$ Millennium BC which I have compiled in [16]. The landscape is represented through grid cells of $25 \times 25 \mathrm{~m}$. Each cell incorporates a set of attributes, which are derived from modern spatial data and are modulated according to paleoenvironmental data on forest cover and soil development. The temporal resolution is one year. The model is driven by the inhabitant's annual demand in calories and timber. 


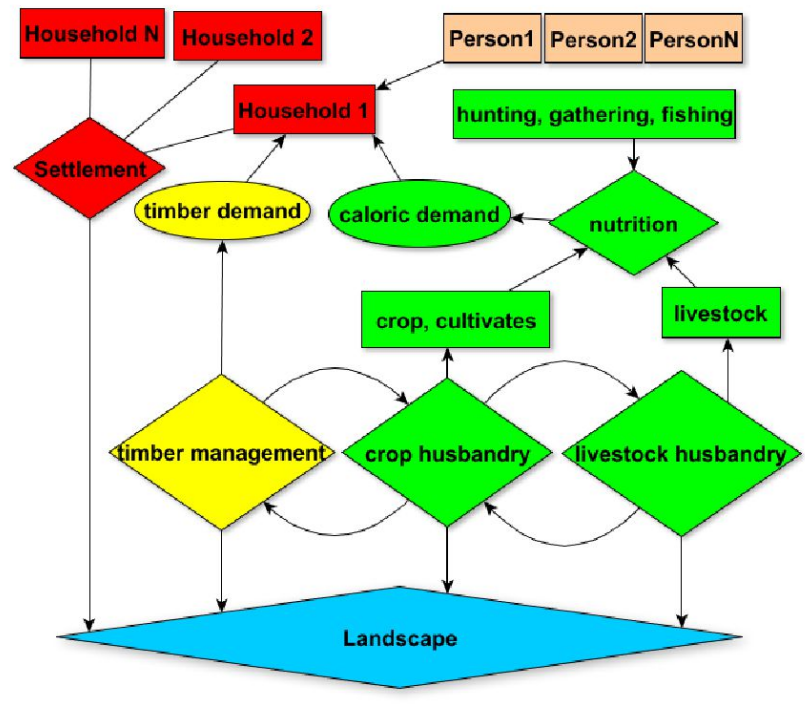

Fig 2. Schema displaying the major elements of the system "prehistoric wetland settlement". Subsystems are drawn as rhombes, the driving forces are drawn in oval shape. Colors are given according to internal relation of the system elements.

The observer has the ability to choose between various options on nutrition strategies and crop husbandry systems, from which a set of different scenarios results. The main discriminating choices are the hypotheses $A$. - C. described in section III, and the diet composition. Either $100 \%, 85 \%$ or $70 \%$ of cereals are formulated as an annual aim of the settlers, $15 \%$ of livestock or $30 \%$ summed up livestock + collected plants + game and fish making up for the rest. The cereal proportion aimed at determines the annual field size of one "household", but annual variation in yields due to weather events is incorporated. Thus, in some years the aim will not be met, and shortage occurs. If hunting/fishing/gathering is part of the nutrition strategy, this loss can be accounted for to some extent. For the crop yield determination, quasi-realistic centennial yield series for the $4^{\text {th }}$ Millennium BC have been simulated using a modern agro-ecosystem model [17]. Processes on different timescales occur. Crop yields, fields size, forest pasture area, and number of "households" are updated every year, while houses have to be rebuilt every 7 to 12 years, and forest regeneration from field or clearing to primary forest needs 50 years. Soil nutrient depletion takes place in NIC, beginning 10 years after the initial cultivation of a field on Luvisol soil type. In contrast to the archaeological record, in the model, the "households" remain on their spot and the inhabitants do not change settlement location. Thus, it can be observed whether phenomena occur that necessitate a shift of habitation under a given scenario.

\section{Results AND Discussion}

WELASSIMO can be seen as a tool that generates surplus value with respect to the inputted data. It dynamically thus allowing for an understanding of the spatial and systemic
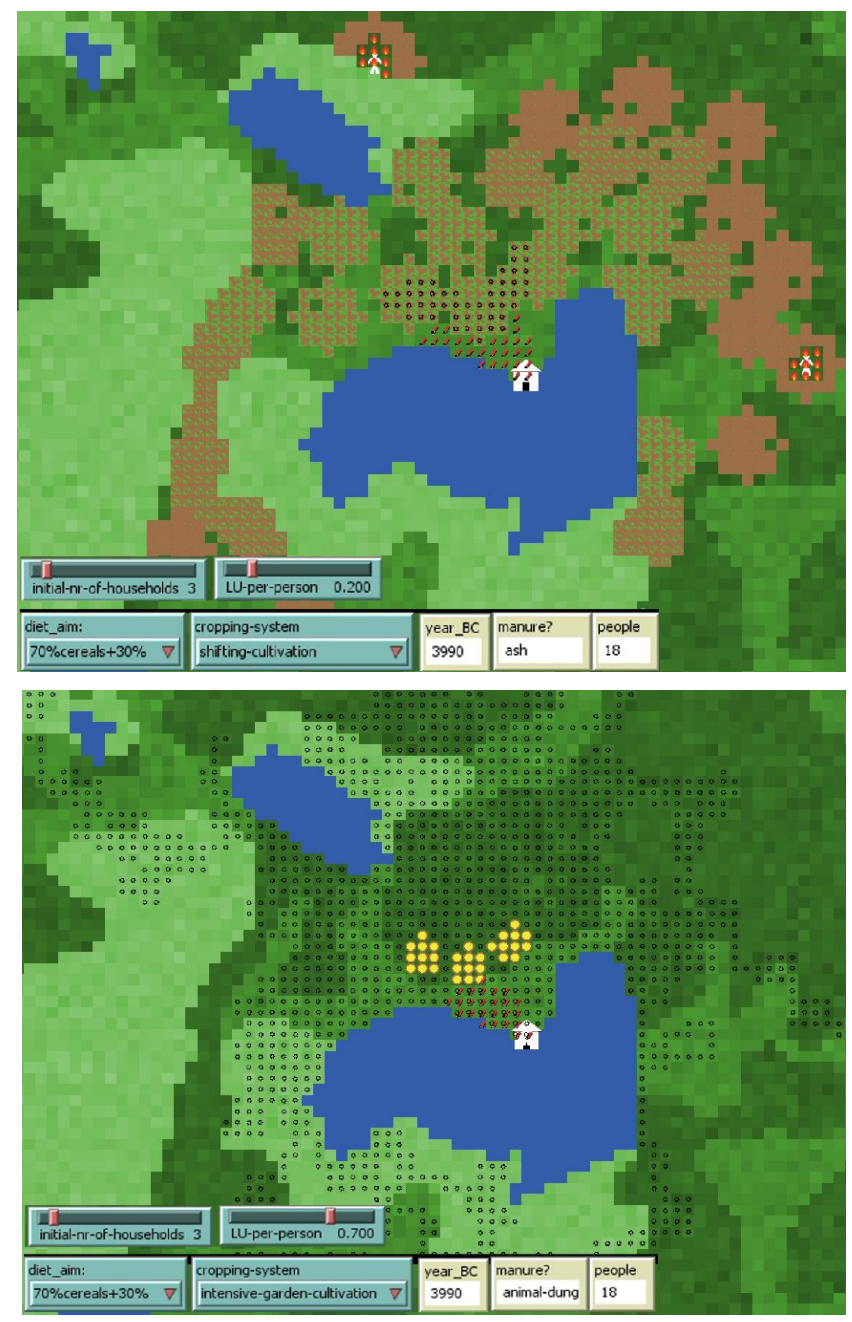

Fig 3a (above) and 3b (below). Two snapshots of a simulation run of WELASSIMO, depicting the situation in year 10 of the settlement. The different land use patterns are due to different crop husbandry regimes as described in the text. Various shades of green represent natural ecosystems; brown areas are cleared from forest 1-2 years ago, incremental dots of green on the brown showing older patches. A yellow spot indicates a cereal field $(25 \times 25 \mathrm{~m})$. Black dots are this years areas for livestock forest pasture, red diagonal logs indicate forest patches where no suitable timber is available due to past logging.

implication of certain hypotheses. An example is shown in fig. $3 a$ and $3 b$, which show a snapshot 10 years after the start of the simulation with the same input parameters (3 initial "households", diet of $70 \%$ cereal $-15 \%$ livestock meat $15 \%$ hunted/gathered food). The difference is in the crop husbandry system, which is SC in $3 \mathrm{a}$ and IGC in $3 \mathrm{~b}$. A very different landscape is simulated as a result of the land use strategies. In 3a, a large area of primary forest has been converted by crop husbandry activities and is now in various stages of forest succession. The annual need for new fields and wood for ash-fertilization leads to relatively large distances to the fields of up to 1150 meters. The quite small area needed for livestock fodder is due to low livestock numbers ( 0.2 per Person) and high quality of leave fodder on secondary growth. In $3 b$, larger permanent fields due to lower 
yields and more livestock ( 0.7 per Person) for manuring reasons are needed. Thus, much more primary forest is conserved, but this is heavily affected by forest pasture and pollarding. Fields may be much closer to the settlement (max. $350 \mathrm{~m}$ ). The major question behind this project is whether any one subsystem calls for a shift of the settlements after some time and necessitates the highly dynamic settlement system that can be reconstructed by dendrochronological dating. The main resources in question are work force, hunting and gathering grounds, timber forest, suitable soil for crop husbandry, and livestock browse area. The work force related to the scenarios is not simulated in detail; but other authors deal with the question of prehistoric work loads, and I have assured that my assumptions are within their ranges [18], [19]. The three crop husbandry subsystems have different implications. SC may necessitate distant fields. With a settlement size of 18 inhabitants, maximum field distances of 1150 meters occur, with 60 inhabitants up to 1800 meters. Systemic benefits may arise: the highly structured catchment may attract game; the fallowing areas make better livestock browsing areas than primary forest, and hazelnut bushes may grow much better here, providing nuts; secondary or coppiced forest has larger numbers of suitable trees. For a group the size of 18-60 applying SC, there arises no direct need for a shifting of their settlements. Only if one assumes that a maximum distance of 1800 meters may be too distant, there would be a case for this Hypothesis. IGC is facilitated by large numbers of livestock and means to collect the dung such as stables, for both of which in the pre-alpine region, there is no evidence in the beginning of the $4^{\text {th }}$ Millennium. If these were proved, contiguous fields and good yields were to assume for decades. The primary forest might be very close to the settlements, though it would show signs of intensive browsing. So also from this Hypothesis, no necessity for high mobility arises.

NIC calls for somewhat larger fields than IGC, but other than that, there is not much difference.

The demand in timber with the right dimensions is quite high. The size of the area to harvest such trees is highly dependent on the composition of the forest stand. If a primary forest is assumed, the necessary timber for one house could be extracted from 0.5-1 ha. From a coppiced stand of 1 ha, however, a multitude of houses can be constructed [20]. Taking 7-12 years as an average house age, for a group of 10 "households" this may make the difference of extracting wood from $10 \mathrm{Ha}$ of primary forest or from one Ha of coppiced forest. I therefore assume that the major resource governing the decision to shift habitation were suitable timber stands. Refinements of WELASSIMO will elaborate on that, accounting also for settlement density in the landscape and transport on water. The integration of detailed data on forest stand dynamics is not yet realized in WELASSIMO due to missing data on suitable modern analogies for the forest in the $4^{\text {th }}$ Millennium BC; building on publications on
Bialowieza National Park (Poland), this will be the next project to integrate in the simulations.

\section{REFERENCES}

[1] F. Menotti Ed., "Living on the Lake in prehistoric Europe", London: Routledge, 2004

[2] S. Jacomet "Plant economy and village life in Neolithic lake dwellings at the time of the Alpine Iceman" Vegetation history and archaeobotany vol. 18, issue 1 pp. 47-59, 2009.

[3] O. Ehrmann, M. Rösch and W. Schier "Experimentelle Rekonstruktion eines jungneolithischen Wald-Feldbaus mit Feuereinsatz." Praehist. Zeitschr. vol. 84, issue 1 pp. 44-72, 2009.

[4] A. Bogaard "Questioning the relevance of shifting cultivation to Neolithic farming in the loess belt of Europe: evidence from the Hambach Forest experiment" Vegetation history and archaeobotany vol. 11, issue 1-2 pp. 155-168, 2002.

[5] R. Ebersbach, "Vom Entstehen und Vergehen. Überlegungen zur Dynamik von Feuchtbodenhäusern und - siedlungen”. In: Vernetzungen. Festschrift für Helmut Schlichtherle. I. Matuschik and C. Strahm Eds. Freiburg: Lavori, 2009, pp. 15-64.

[6] B. Diekmann, A. Harwath, J. Hoffstadt, A. Billamboz "HornstaadHörnle 1A. Die Befunde einer jungneolithischen Pfahlbausiedlung am westlichen Bodensee". Siedlungsarch. im Alpenvorland 9, Forsch.Ber.Ur-u.Frühgesch. Ba-Wü. Stuttgart: Theiss, 2006

[7] I. Matuschik, "Die Keramikfunde von Hornstaad-Hoernle I-VI Besiedlungsgeschichte der Fundstelle und Keramikentwicklung im 4. Jtsd. v. Chr. im Bodenseeraum". Siedlungsarch. im Alpenvorland 12, Forsch.Ber.Ur-u.Frühgesch. Ba-Wü. Stuttgart: Theiss 2013

[8] U. Maier, R. Vogt, M. Ahrens: Botanische und pedologische Untersuchungen zur Ufersiedlung Hornstaad-Hörnle IA. Siedlungsarchäologie im Alpenvorland 6. Forsch. Ber. Ur-u. Frühgesch. Ba-Wü. Stuttgart: Theiss

[9] T. Doppler, S. Pichler, B. Röder, J. Schibler, "Coping with Crises 1: Subsistence variety and resilience in the neolithic lake shore settlement Arbon-Bleiche 3 (Switzerland)" in: T Kerig and A. Zimmermann Eds., Economic Archaeology. From structure to perfomance in European Archaeology. Universitätsforschungen zur prähistorischen Archäologie 237. Bonn: Habelt, 2013

[10] A. Billamboz J. Köninger, "Dendroarchäologische Untersuchungen zur Besiedlungs- und Landschaftsentwicklung des westlichen Bodenseegebietes" in: W. Dörfler and J. Müller Eds.: UmweltWirtschaft-Siedlungen im dritten vorchristlichen Jahrtausend Mitteleuropas und Südskandinaviens, Neumünster: Wachholtz, 2008

[11] U. Maier et al.,"Das DFG-Projekt Degersee: Fortgang der Arbeiten und neue Entdeckungen" Archäologische Ausgrabungen von BadenWürttemberg, Stuttgart: Theiss, 2010

[12] E. Gross, S. Jacomet, J. Schibler, "Stand und Ziele der wirtsch.arch. Forschung an neolit. Ufer- und Inselsiedlungen im unteren Zürichseeraum.” In: J. Schibler, J. Sedlmaier, H. Spycher Eds.: Festschrift H. Stampfli. Basel: Helbig/Lichtenhahn 1990, pp. 77-100

[13] M. Charles, G. Jones, and J. G. Hodgson. "FIBS in archaeobotany: functional interpretation of weed floras in relation to husbandry practices." Journal of Arch. Science 24.12 (1997): 1151-1161.

[14] A. Bogaard et al. "Crop manuring and intensive land management by Europe's first farmers" Proceedings of the National Academy of Sciences vol. 110, issue 31 pp. 12589-12594, 2013.

[15] R. Ebersbach, "Quantitative approaches to prehistoric stock breeding" in: T. Kerig and A. Zimmermann Eds., Economic Archaeology. From structure to perfomance in European Archaeology. Universitätsforschungen zur prähist. Arch. 237. Bonn: Habelt, 2013

[16] T. Baum, "Models of wetland settlement and associated land use in South-West Germany during the fourth millennium BC". Vegetation history and archaeobotany vol. 23 , issue 1 pp. 67-80, 2014

[17] C. Nendel et al., "The MONICA model. Testing predictability for crop growth ....". Ecological modeling 222, issue 9, 1614-1625, 2011

[18] T Kerig, "Als Adam grub... Vergleichende Anmerkungen zu landwirtschaftlichen Betriebsgrößen in prähistorischer Zeit" Ethnografisch-archäologische Zeitschrift, 375-402, 2007

[19] T Kerig and A. Zimmermann Eds., Economic Archaeology. From structure to perfomance in European Archaeology. Universitätsforschungen zur prähist. Arch. 237. Bonn: Habelt, 2013

[20] N. Bleicher, "Altes Holz in neuem Licht" Stuttgart: Theiss, 2009 